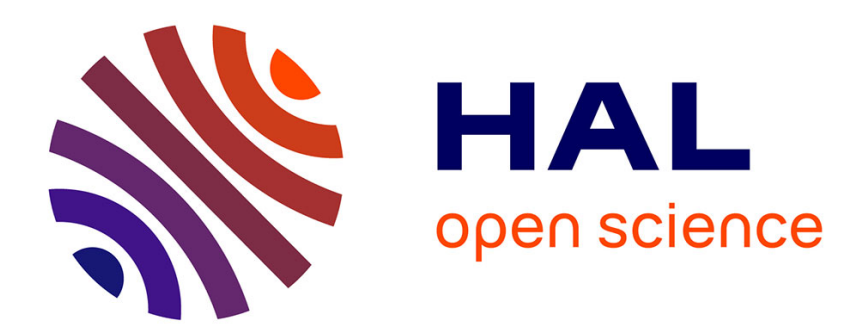

\title{
Genetic parameters and character association for clonal selection in potato breeding programmes
}

Jai Gopal

\section{To cite this version:}

Jai Gopal. Genetic parameters and character association for clonal selection in potato breeding programmes. Agronomie, 1999, 19 (6), pp.531-539. hal-00885951

\section{HAL Id: hal-00885951 https://hal.science/hal-00885951}

Submitted on 1 Jan 1999

HAL is a multi-disciplinary open access archive for the deposit and dissemination of scientific research documents, whether they are published or not. The documents may come from teaching and research institutions in France or abroad, or from public or private research centers.
L'archive ouverte pluridisciplinaire $\mathbf{H A L}$, est destinée au dépôt et à la diffusion de documents scientifiques de niveau recherche, publiés ou non, émanant des établissements d'enseignement et de recherche français ou étrangers, des laboratoires publics ou privés. 


\title{
Genetic parameters and character association for clonal selection in potato breeding programmes
}

\author{
Jai Gopal \\ Division of Genetics and Plant Breeding, Central Potato Research Institute, Shimla-171 001, HP, India
}

(Received 26 April 1999; accepted I June 1999)

\begin{abstract}
In order to plan a strategy for clonal selection in potato, the behaviour of genetic parameters, namely coefficient of variation (both phenotypic and genotypic), heritability (broad sense) and genetic advance (as percentage of mean), and correlation coefficients (both phenotypic and genotypic) for 12 characters in 22 genotypes were studied under diverse seasons (two autumn and two spring) in the sub-tropical north-western plains of India. All parameters were affected by season as well as by year. Based on the magnitude and consistency of parameters for various characters it was concluded that simultaneous selection for plant vigour, average tuber weight and tuber yield would be effective in improving tuber yield in potato. Selection for breeder's preference score at harvest should also be effective in improving the overall worth of a clone. (C) Inra/Elsevier, Paris.)
\end{abstract}

potato breeding / heritability / genetic advance / correlations / selection procedure

Résumé - Paramètres génétiques et associations de caractères pour la sélection clonale dans les programmes d'amélioration de la pomme de terre. Dans le but d'établir une stratégie pour la sélection clonale de la Pomme de terre, le comportement d'un certain nombre de caractères, en particulier le coefficient de variation (phénotypique et génotypique), l'héritabilité au sens large, le progrès génétique (en \% de la moyenne), et les corrélations (phénotypiques et génotypiques) ont été étudiés pour 12 caractères chez 22 génotypes à différentes saisons (deux automnes et deux printemps) dans le climat subtropical des plaines du Nord-Ouest de l'Inde. Tous les paramètres sont affectés par la saison et par l'année. En fonction de l'ampleur et de la cohérence des paramètres de ces caractères, on peut conclure que la sélection simultanée pour la vigueur de la plante, le poids moyen de tubercule et le rendement en tubercules pourrait s'avérer efficace pour améliorer le rendement. La sélection pour un score « de préférence » du sélectionneur à la récolte pourrait également être efficace pour améliorer la valeur globale d'un clone. (@ Inra/Elsevier, Paris.)

pomme de terre / amélioration / héritabilité / progrès génétique / corrélations / sélection

Communicated by Mervyn Humphreys (Aberystwyth, UK)

* Correspondence and reprints

jai_gopal@cpri.hp.nic.in 


\section{Introduction}

Studies on genetic parameters and character associations provide information about the expected response of various characters to selection and help in developing optimum breeding procedures. However, such studies in potato (Solanum tuberosum L.) have not led to any consensus. Dayal et al. [5], Gaur et al. [8], Sidhu and Pandita [17] and Garg and Bhutani [7] reported that selection for tuber yield should produce a higher genetic advance than selection on its components tuber number and average tuber weight, whereas Chaudhary and Sharma [4] and Birhman and Kaul [2] reported higher genetic advance for tuber number than for tuber yield and average tuber weight. Tai [21], Killick [13], Thompson et al. [24] and Gopal et al. [12] found higher heritability for average tuber weight than for tuber number, whereas Maris [14] found little difference in the heritability values of these characters.

Similarly, there is no consensus with regard to character association in potato. Singh and Singh [20] and Maris [15] reported a significant association between plant height and tuber yield, whereas Patel et al. [16], Sidhu et al. [18] and Desai and Jaimini [6] reported that plant height was of little importance for tuber yield. Among tuber yield components, Maris [14] and Gopal et al. [12] reported that both average tuber weight and tuber number are associated with tuber yield but average tuber weight has a stonger correlation with tuber yield. However, Thompson and Mendoza [23] and Maris [15] reported that tuber number is more important than average tuber weight, although Gaur et al. [9] found no relationship between tuber number and tuber yield. Desai and Jaimini [6] found no relationship between average tuber weight and tuber yield, but Tarn and Tai [22] found similar correlation coefficients between tuber number and tuber yield and between average tuber weight and tuber yield in Tuberosum families. The relationship between tuber number and average tuber weight has been reported to be non-significant $[6,17,23]$ as well as highly significant and negative $[9,16,24]$. Many such variations have been reported for other characters as well.
These variations may be due to the type of material used and the environmental conditions to which genotypes were subjected. Further, most of these studies were based on only 1 year's data. Thus, the need remains to elucidate and develop a broad strategy for clonal selection aimed at improving tuber yield and other agronomic characters in potato breeding programmes. That was attempted in this investigation by studying genetic parameters and character associations in the diverse agroclimates of autumn and spring for 2 years in the north-western plains of India. In this region, the main potato crop is taken during the autumn season (October-January) and a supplementary crop during the spring season (January/February-April/May). The autumn season has short days (10-11 h) and low temperatures $\left(\max\right.$. temp.: mean $=24.3{ }^{\circ} \mathrm{C}$, range $=$ 19.0-32.5 ${ }^{\circ} \mathrm{C}$ and min. temp.: mean $=10.0^{\circ} \mathrm{C}$, range $=4.0-17.3{ }^{\circ} \mathrm{C}$ ). These conditions are more favourable to tuberization than to foliage growth. The spring season has long days (14-15 h) and high temperatures $\left(\max\right.$ temp.: mean $=29.7{ }^{\circ} \mathrm{C}$, range $=19.0-39.6{ }^{\circ} \mathrm{C}$ and $\mathrm{min}$. temp.: mean $=15.8{ }^{\circ} \mathrm{C}$, range $=7.0-23.7^{\circ} \mathrm{C}$ ). These conditions are more conducive to foliage growth than to tuberization. This region thus offers an ideal situation for investigating the behaviour of genetic parameters and character associations in potato under diverse conditions.

\section{Materials and methods}

A random sample of 22 potato genotypes was used in this study. Eighteen of these genotypes, viz. AB455, E4451, F1277, JE812, JH222, JN1501, JR465, JTH/C107, MS78-46, MS78-56, MS79-34, MS80-758, MS81-152, MS82-638, MS84-1169, PJ376, RG1197 and SLB/K23, were clones from Indian potato breeding programmes and four genotypes, namely CP 1710 , CP2132, EX/A680-16 and EX/A723, were germplasm accessions. These were evaluated in two autumn seasons during 1994-1995 and 1995-1996 and two spring seasons during 1994 and 1995 at the Punjab Agricultural University, Ludhiana $\left(31^{\circ} \mathrm{N}, 75^{\circ} \mathrm{E}, 230 \mathrm{~m}\right.$ above sea level). All field experiments were designed in a completely randomized block with three replications 
in short rows of five tubers each ( 15 tubers per clone per plot) at the recommended intra- and inter-row distance of 20 and $60 \mathrm{~cm}$, respectively. Normal manurial and cultural schedules were followed. Haulms cutting was carried out at maturity. The dates of sowing, haulms cutting and harvesting were as given below:

\begin{tabular}{|c|c|c|c|}
\hline \multirow[t]{2}{*}{ Crop season } & \multicolumn{3}{|c|}{ Date(s) of } \\
\hline & Sowing & $\begin{array}{l}\text { Haulms } \\
\text { cutting }\end{array}$ & Harvesting \\
\hline $\begin{array}{l}\text { Autumn } \\
\text { 1994-1995 }\end{array}$ & $\begin{array}{c}11 \text { th } \\
\text { Oct. } 1994\end{array}$ & $\begin{array}{c}\text { 9th } \\
\text { Feb. } 1995\end{array}$ & $\begin{array}{c}\text { Ist } \\
\text { March } 1995\end{array}$ \\
\hline $\begin{array}{l}\text { Autumn } \\
\text { 1995-96 }\end{array}$ & $\begin{array}{c}\text { 28th } \\
\text { Sept. } 1995\end{array}$ & $\begin{array}{c}\text { 18th } \\
\text { Jan. } 1996\end{array}$ & $\begin{array}{c}21 \mathrm{st} \\
\text { Jan. } 1996\end{array}$ \\
\hline Spring 1994 & $\begin{array}{c}\text { 2nd } \\
\text { Feb. } 1994\end{array}$ & $\begin{array}{c}21 \text { st } \\
\text { May } 1994\end{array}$ & $\begin{array}{c}21 \mathrm{st} \\
\text { May } 1994\end{array}$ \\
\hline Spring 1995 & $\begin{array}{c}5 \text { th } \\
\text { Jan. } 1995\end{array}$ & $\begin{array}{c}\text { 20th } \\
\text { May } 1995\end{array}$ & $\begin{array}{c}\text { 20th } \\
\text { May } 1995\end{array}$ \\
\hline
\end{tabular}

\subsection{Characters recorded}

Data for 12 characters were recorded. Foliage characters were recorded at full growth ( 80 days after sowing) on five competitive plants (i.e. the best growing plants) per plot and tuber characters on a plot basis at maturity. The characters were: plant vigour (score 1-5: $1=$ very high, $5=$ very poor); plant posture (score $1-3: 1=$ erect, $3=$ prostrate); number of main stems per plant, plant height $(\mathrm{cm})$, number of nodes per plant (on the longest stem only), internode length $(\mathrm{cm})$, maturity (days to senescence of $50 \%$ foliage), tuber yield per plant $(\mathrm{g})$, tuber number per plant, average tuber weight $(\mathrm{g})$, number of eyes per tuber and breeder's preference score based on overall tuber characters (score: 1-5: $1=$ very high, 5 = very low).

\subsection{Statistical methods}

Data were subjected to analyses of variance and covariance [19]. For each character the following parameters were computed:

phenotypic coefficient of variation: $100 \sqrt{ } \sigma_{p}^{2} / \bar{x}$

genotypic coefficient of variation: $100 \sqrt{ } \sigma_{\mathrm{g}}^{2} / \overline{\mathrm{x}}$

heritability in broad sense: $\sigma_{\mathrm{g}}^{2} / \sigma_{\mathrm{p}}^{2} \overline{\mathrm{x}}$ genetic advance (as \% of mean): (S. $\sigma^{2}{ }_{q} / N \sigma_{p}^{2}$ ) $100 / \bar{x}$ where $\sigma^{2}$ is genotype mean square/number of replications, $\sigma_{\mathrm{g}}^{2}$ is (genotype mean square - error mean square)/number of replications, $\overline{\mathrm{x}}$ is the population mean, $\mathrm{S}$ is selection differential for $5 \%$ selection $(=2.06)$

Phenotypic and genotypic correlation coefficients between characters in all combinations were computed as:

phenotypic correlation coefficient: $\sigma^{2 \mathrm{p}}{ }_{(\mathrm{clc} 2)} / \sqrt{\sigma^{2 \mathrm{p}}}{ }_{(\mathrm{cl})}$ $\sigma^{2 \mathrm{p}}(\mathrm{c} 2)$

genotypic correlation coefficient: $\sigma_{\mathrm{g}(\mathrm{clc} 2)}^{2} / \sigma^{2}{ }_{\mathrm{g}(\mathrm{c} 1)}$ $\sigma_{\mathrm{g}(\mathrm{c} 2)}^{2}$

where $\sigma^{2 \mathrm{p}}(\mathrm{cl}, \mathrm{c} 2)$ is the genotype mean product of characters $c 1$ and $c 2$ /number of replications, $\sigma_{\mathrm{g}(\mathrm{cl}, \mathrm{c} 2)}$ is (genotype mean product of characters $\mathrm{c} 1$ and $\mathrm{c} 2$ - error mean product)/number of replications.

Computer software SPAR-1 (IASRI, New Delhi) was used for these computations.

\section{Results}

Analysis of variance showed highly significant $(P<0.01)$ genotypic differences for all characters in all the trials.

\subsection{Coefficient of variation}

Phenotypic coefficients of variation (PCV) were higher than the corresponding genotypic coefficients of variation (GCV) for all characters. Sufficient variation was present at the phenotypic as well as the genotypic level for selection to be effective for various characters (table $I$ ). The highest coefficient of variation (both PCV and GCV) was observed for tuber number in the spring season and for plant height in the autumn season (average over years). Average coefficient of variation in the autumn season was higher than in the spring season for plant height, number of nodes and internode length, whereas a reverse trend was observed for tuber yield, tuber number and number of eyes. Such marked differences were, however, not observed for other characters. The most consistent coefficients of variation (both PCV and GCV) over seasons and years were for average tuber weight 
Table I. Phenotypic and genotypic coefficients of variation for various characters in potato.

\begin{tabular}{lcccccccc}
\hline Character & \multicolumn{3}{c}{ Phenotypic coefficient of variation } & \multicolumn{3}{c}{ Genotypic coefficient of variation } \\
\cline { 2 - 9 } & Sp 94 & Sp 95 & Au 94-95 & Au 95-96 & Sp 94 & Sp 95 & Au 94-95 & Au 95-96 \\
\hline Plant height & 26.91 & 28.03 & 40.80 & 39.54 & 25.02 & 25.71 & 38.47 & 35.53 \\
No. of nodes & 14.33 & 20.55 & 23.55 & 17.91 & 11.22 & 17.12 & 20.08 & 14.45 \\
Internode length & 23.39 & 18.82 & 34.70 & 27.99 & 19.76 & 14.80 & 32.20 & 25.20 \\
No. of stems & 41.46 & 37.70 & 35.87 & 39.31 & 29.20 & 26.72 & 28.29 & 34.25 \\
Tuber yield & 72.84 & 33.90 & 27.14 & 36.57 & 56.32 & 27.06 & 20.47 & 32.08 \\
Tuber number & 81.51 & 43.68 & 26.78 & 42.85 & 64.32 & 36.47 & 17.87 & 36.26 \\
Av. tuber weight & 38.81 & 39.68 & 38.60 & 38.68 & 27.28 & 27.71 & 27.74 & 33.20 \\
No. of eyes & 19.09 & 19.22 & 17.24 & 16.30 & 16.69 & 16.61 & 14.97 & 16.69 \\
Plant vigour & 32.82 & 36.29 & 37.45 & 31.48 & 30.90 & 31.52 & 32.13 & 28.44 \\
Plant posture & 27.31 & 17.92 & 22.53 & 18.01 & 20.96 & 7.69 & 18.05 & 16.19 \\
Maturity & 39.63 & 23.37 & 35.78 & 26.59 & 37.23 & 21.28 & 32.86 & 24.09 \\
Breeder's & 27.33 & 27.33 & 27.75 & 27.99 & 24.24 & 24.24 & 24.64 & 24.30 \\
preference score & & & & & & & & \\
\hline
\end{tabular}

Sp, spring; Au, autumn.

and breeder's preference score. The most inconsistent characters were tuber number and tuber yield. Number of eyes had a similar coefficient of variation in the 2 years within a season.

\subsection{Heritability and genetic advance}

Heritability values for various characters varied between seasons as well as between years within a season (table II) but ranged between moderate $(\approx 0.50-0.75)$ to high ( $>0.75)$. Plant height, number of eyes, plant vigour, maturity and breeder's preference score, in general, had high heritabilities in both seasons, whereas number of nodes, number of stems, tuber yield, tuber number, average tuber weight and plant posture had moderate heritabilities. Heritability for internode length was moderate in the spring season and high in the autumn season.

Expected genetic advance was converted into percentage of clones' mean so that comparison could be made among various characters which had different units of measurement. These values varied with character, season and year. The maximum fluctuation in genetic advance was for tuber number and ranged between $24.57 \%$ in autumn $1994-1995$ and $104.46 \%$ in spring 1994 . Genetic advance for tuber yield also showed big fluctuations (31.55\% in autumn 1994-1995 to $89.70 \%$ in spring 1994). In contrast, genetic advance of average tuber weight, breeder's preference score and plant vigour moved in a narrow range of moderate values, i.e. $39.52-58.69,34.89-44.91$ and $52.82-65.63 \%$, respectively. Number of nodes, number of eyes and plant posture, in general, had low values of genetic advance ranging between 18.09 and $35.24,26.83$ and 32.78 , and 27.03 and $49.65 \%$, respectively. Plant height and maturity had moderate to high values of genetic advance, whereas the values for internode length and number of stems were of low to moderate magnitude (table II). Genetic advance was higher in the autumn than in the spring season for plant height, internode length, number of stems and average tuber weight. For other characters no consistent pattern was observed in this respect.

\subsection{Character association}

Most of the correlation coefficients were nonsignificant. Significant ones are presented in table III. Genotypic correlation coefficients $\left(\mathrm{r}_{\mathrm{g}}\right)$ were, in general, higher than the phenotypic corre- 
Table II. Heritability and genetic advance for various characters in potato.

\begin{tabular}{lcccccccc}
\hline Character & \multicolumn{4}{c}{ Heritability } & \multicolumn{3}{c}{ Expected genetic advance (\% of mean) } \\
\cline { 2 - 9 } & Sp 94 & Sp 95 & Au 94-95 & Au 95-96 & Sp 94 & Sp 95 & Au 94-95 & Au 95-96 \\
\hline Plant height & 0.86 & 0.84 & 0.89 & 0.81 & 47.89 & 48.58 & 74.72 & 65.76 \\
No. of nodes & 0.61 & 0.69 & 0.73 & 0.65 & 18.09 & 29.38 & 35.24 & 23.99 \\
Internode length & 0.71 & 0.62 & 0.86 & 0.81 & 34.15 & 23.94 & 61.71 & 47.13 \\
No. of stems & 0.49 & 0.50 & 0.62 & 0.76 & 42.18 & 38.99 & 45.93 & 61.54 \\
Tuber yield & 0.60 & 0.64 & 0.56 & 0.77 & 89.70 & 44.49 & 31.55 & 57.98 \\
Tuber number & 0.62 & 0.70 & 0.45 & 0.72 & 104.46 & 62.74 & 24.57 & 63.18 \\
Av. tuber weight & 0.49 & 0.49 & 0.53 & 0.74 & 39.52 & 39.85 & 41.67 & 58.69 \\
No. of eyes & 0.77 & 0.75 & 0.75 & 0.98 & 30.09 & 29.62 & 26.83 & 32.78 \\
Plant vigour & 0.74 & 0.75 & 0.74 & 0.82 & 65.63 & 56.49 & 56.91 & 52.82 \\
Plant posture & 0.64 & 0.71 & 0.64 & 0.81 & 49.65 & 27.03 & 29.91 & 29.82 \\
Maturity & 0.88 & 0.83 & 0.84 & 0.82 & 72.13 & 43.56 & 62.23 & 45.03 \\
Breeder's & 0.79 & 0.79 & 0.79 & 0.77 & 44.41 & 44.41 & 44.91 & 34.89 \\
preference score & & & & & & & & \\
\hline
\end{tabular}

Sp, spring; Au, autumn.

lation coefficients $\left(r_{p}\right)$. Most of these are of moderate magnitude $(\approx 0.50-0.75)$. However, correlation coefficients between plant height and internode length in autumn seasons were of high magnitude $\left(r_{p}=0.87 ; r_{g}=0.90-0.93\right)$.

Correlation coefficients (both phenotypic and genotypic) which were significant in both the seasons and in both the years in a season were between: plant height and number of nodes $\left(r_{p}=0.43-0.77\right.$; $\left.r_{g}=0.43-0.81\right)$, plant height and internode length $\left(r_{p}=0.64-0.87 ; r_{g}=0.75-0.93\right)$, tuber yield and average tuber weight $\left(r_{p}=0.43-0.73 ; r_{g}=0.44-0.78\right)$ and tuber yield and plant vigour $\left(r_{p}=-0.43\right.$ to $-0.61 ; r_{g}=-0.64$ to -0.91 ).

The correlation coefficients which were significant in both years for the spring season only were between: plant height and breeder's preference score $\left(r_{p}=0.43-0.49 ; r_{g}=0.46-0.62\right)$, plant height and maturity $\left(r_{p}=0.45-0.49 ; r_{g}=0.51-0.54\right)$, number of nodes and plant vigour $\left(r_{p}=-0.43\right.$ to $-0.49 ; r_{g}=-0.44$ to -0.75$)$, internode length and maturity $\left(r_{p}=0.43-0.44 ; r_{g}=0.51-0.57\right)$ and internode length and breeder's preference score $\left(r_{p}=0.49-0.61 ; r_{g}=0.69-0.85\right)$. On the other hand, the correlation coefficients which were significant in both years for the autumn season only were between: plant height and plant posture $\left(r_{p}=0.54-0.62 ; r_{g}=0.70-0.82\right)$, internode length and plant posture $\left(r_{p}=0.51-0.67 ; r_{g}=0.71-0.87\right)$ and average tuber weight and breeder's preference score $\left(r_{p}=-0.43\right.$ to $-0.45 ; r_{g}=-0.68$ to -0.71$)$.

Some correlations were significant in only one year for only one or both the seasons (table III). The important ones among these were: number of stems with tuber number in spring $1994\left(r_{p}=0.53\right.$; $\left.r_{g}=0.57\right)$ and autumn 1995-1996 $\left(r_{p}=0.55\right.$; $\left.r_{\mathrm{g}}=0.81\right)$, tuber yield with tuber number in spring $1994\left(r_{p}=0.69 ; r_{g}=0.69\right)$ and autumn 1995-1996 $\left(r_{p}=0.50 ; r_{g}=0.55\right)$, tuber number with average tuber weight in spring $1995\left(r_{p}=-0.52 ; r_{g}=-0.52\right)$ and autumn 1994-1995 $\left(r_{p}=-0.61 ; r_{g}=-0.69\right)$ and plant posture with breeder's preference score in spring $1994\left(\mathrm{r}_{\mathrm{p}}=0.44 ; \mathrm{r}_{\mathrm{g}}=0.64\right)$ and autumn 1994-1995 $\left(r_{\mathrm{p}}=0.50 ; \mathrm{r}_{\mathrm{g}}=0.71\right)$.

For some character combinations only genotypic correlation coefficients were significant in one or both years. These combinations were: tuber yield with maturity and number of nodes; internode length with tuber number and plant vigour; number of nodes with tuber number and plant posture; and plant vigour with maturity and breeder's preference score. 
Table III. Significant phenotypic and genotypic correlation coefficients between various characters in potato.

\begin{tabular}{|c|c|c|c|c|c|c|c|c|}
\hline \multirow[t]{2}{*}{ Character } & \multicolumn{4}{|c|}{ Phenotypic coefficient of variation } & \multicolumn{4}{|c|}{ Genotypic coefficient of variation } \\
\hline & Sp 94 & Sp 95 & Au 94-95 & $\mathrm{Au} 95-96$ & Sp 94 & Sp 95 & $\mathrm{Au} 94-95$ & Au $95-96$ \\
\hline PH-NN & $0.53 *$ & $0.72 * *$ & $0.43^{*}$ & $0.77 * *$ & $0.65^{* *}$ & $0.79 * *$ & $0.43 *$ & $0.81^{* *}$ \\
\hline PH-IL & $0.74 * *$ & $0.64 * *$ & $0.87^{* * *}$ & $0.87 * *$ & $0.84 * *$ & $0.75^{* *}$ & $0.93 * *$ & $0.90 * *$ \\
\hline PH-PV & - & $-0.50^{*}$ & - & - & - & $-0.61 * *$ & $-0.46^{*}$ & - \\
\hline PH-POS & - & - & $0.62 * *$ & $0.54 * *$ & - & - & $0.82 * *$ & $0.70 * *$ \\
\hline PH-MAT & $0.49 *$ & $0.45 *$ & - & $0.46^{*}$ & $0.54 * *$ & $0.51 *$ & - & $0.52 *$ \\
\hline PH-BPS & $0.49 *$ & $0.43 *$ & $0.59 * *$ & - & $0.62 * *$ & $0.46 *$ & $0.75 * *$ & - \\
\hline NN-TY & - & - & - & - & - & $0.51 *$ & - & - \\
\hline NN-TN & - & - & - & - & - & $0.62 * *$ & - & - \\
\hline NN-PY & $-0.43 *$ & $-0.49 *$ & - & - & $-0.44 *$ & $-0.75^{* *}$ & - & - \\
\hline NN-POS & - & - & - & - & - & $0.71 * *$ & - & - \\
\hline IL-NS & - & $0.53 *$ & - & - & $0.46^{*}$ & $0.63 * *$ & - & - \\
\hline IL-TY & - & - & - & $0.45^{*}$ & - & - & - & $0.54 * *$ \\
\hline IL-TN & - & - & - & - & - & - & $0.50 *$ & $0.58 * *$ \\
\hline IL-PV & - & - & - & - & - & - & $-0.50^{*}$ & $-0.44^{*}$ \\
\hline IL-POS & - & - & $0.67 * *$ & $0.51^{*}$ & - & - & $0.87 * *$ & $0.71 * *$ \\
\hline IL-MAT & $0.44 *$ & $0.43^{*}$ & - & - & $0.51 *$ & $0.57 * *$ & - & - \\
\hline IL-BPS & $0.61 * *$ & $0.49 *$ & $0.57 * *$ & - & $0.85^{* *}$ & $0.69 * *$ & $0.70^{* *}$ & - \\
\hline NS-TY & $0.50^{*}$ & - & - & - & $0.56 * *$ & - & - & - \\
\hline NS-TN & $0.53^{*}$ & - & - & $0.55^{* *}$ & $0.57 * *$ & - & $0.58 * *$ & $0.81 * *$ \\
\hline NS-POS & $0.49^{*}$ & - & - & - & $0.79 * *$ & - & - & - \\
\hline NS-MAT & - & $0.44 *$ & - & - & - & $0.69 * *$ & - & - \\
\hline NS-BPS & - & $0.44 *$ & - & - & $0.51 *$ & $0.62 * *$ & - & - \\
\hline $\mathrm{TY}-\mathrm{TN}$ & $0.69 * *$ & - & - & $0.50 *$ & $0.69 * *$ & - & - & $0.55 * *$ \\
\hline TY-ATW & $0.43^{*}$ & $0.55^{* *}$ & $0.73 * *$ & $0.53 *$ & $0.44 *$ & $0.64 * *$ & $0.78^{* *}$ & $0.59 * *$ \\
\hline TY-PV & $-0.45^{*}$ & $-0.61 * *$ & $-0.43 *$ & $-0.54 * *$ & $-0.75 * *$ & $-0.91^{* *}$ & $-0.82 * *$ & $-0.64 * *$ \\
\hline TY-MAT & - & - & - & - & - & $0.55 * *$ & - & $0.43 *$ \\
\hline TY-BPS & - & - & - & $-0.58 * *$ & - & - & - & $-0.70 * *$ \\
\hline TN-ATW & - & $-0.52 *$ & $-0.61 * *$ & - & - & $-0.52 *$ & $-0.69 * *$ & - \\
\hline TN-BPS & - & - & $0.43 *$ & - & - & - & $0.71^{* *}$ & - \\
\hline ATW-PV & - & - & - & $-0.53^{*}$ & - & $-0.55^{* *}$ & - & $-0.72 * *$ \\
\hline ATW-BPS & - & - & $-0.43^{*}$ & $-0.45^{*}$ & - & $-0.51 *$ & $-0.71^{* *}$ & $-0.68^{* *}$ \\
\hline PV-MAT & - & - & - & - & - & $-0.54 * *$ & - & - \\
\hline PV-BPS & - & - & - & - & - & - & - & $0.55^{* *}$ \\
\hline POS-BPS & $0.44 *$ & - & $0.50^{*}$ & - & $0.64 * *$ & - & $0.71^{* *}$ & $0.54 * *$ \\
\hline
\end{tabular}

*,** Significant at $P<0.05,0.01$, respectively.

- : non-significant.

Sp, spring; Au, autumn.

PH, plant height; NN, number of nodes; IL, internode length; NS, number of stems; TY, tuber yield; TN, tuber number; ATW, average tuber weight; NE, number of eyes; PV, plant vigour; POS, plant posture; MAT, maturity; BPS, breeder's preference score. 


\section{Discussion}

Individual clonal selection is known to be inefficient in early generations of potato breeding programmes $[1,3,11,15]$, mainly because of large error and sampling variations due to inaccuracy of selecting on small plots (initially often individual plants). In these generations only negative selection is recommended for various agronomic characters such as tuber yield and its components [11, 15]. The present study was based on advanced stage clones and some germplasm accessions where material was not limited and statistically sound replicated trials could be conducted. The results based on this study can thus be reliably used in advance stages of potato breeding programmes where positive selection is practised for various characters. The highly significant genotypic differences observed for various characters indicate the suitability of this material for the present study. The choice of the various characters studied was based on their reported importance to tuber yield. In addition, plant posture, number of eyes, maturity and breeder's preference score were also studied as there was little previous information available on these characters.

Higher values for phenotypic coefficients of variation than genotypic coefficients of variation indicate the presence of environmental variation which also resulted in lower phenotypic correlation coefficients compared to corresponding genotypic correlation coefficients between various characters. However, moderate to high values of heritability observed for various characters indicate that environmental variation could be limited by the design used. Heritability is, in reality, a measure of the efficiency of an evaluation system in separating genotypes. The introduction of clonal replication into the system obviously increased the size of the heritability values.

Higher coefficients of variation for plant height, number of nodes and internode length in the autumn than in the spring season, and the reverse pattern for tuber yield and tuber number, suggest that under conditions adverse to the expression of a character, genotypic differences are enlarged for that character. This supports our earlier observation [10] where genotypic differences under in vitro conditions were higher as compared to in vivo conditions.

Genetic parameters as well as correlation coefficients were consistent over seasons and years for some characters, whereas for others these varied. From a breeding point of view, a character which is less affected by change of season and/or year is easier to handle. Among tuber yield, tuber number and average tuber weight, the last character was the most consistent with regard to coefficient of variation as well as genetic advance. Tuber yield and number of tubers tended to be the most inconsistent among all the characters studied. Correlation coefficients between average tuber weight and tuber yield were moderate, but significant over all years and seasons. On the other hand, correlation coefficients between tuber number and tuber yield were highly inconsistent and varied even in different years of the same season. So, it would not be advisable to use tuber number as a selection parameter to improve tuber yield. Rather, average tuber weight would be a better choice. Tuber yield had good variation, reasonable heritability and good genetic advance which were comparable to or even higher than those for average tuber weight in certain years. So combined selection for tuber yield and average tuber weight should be a better strategy for improving tuber yield. Tuber number was negatively associated with average tuber weight in two of the four environments studied. Thus, to avoid the risk of selecting clones with fewer, oversized tubers, it is suggested that a standard may be fixed for the minimum number of tubers required in the selected types before employing selection for tuber yield and average tuber weight. These findings endorse our earlier recommendation [12].

Among the foliage characters, consistent correlation coefficients were found between plant height and number of nodes and plant height and internode length. The positive and moderate to high correlation coefficients between these pairs indicate that a change in plant height is accompanied by a corresponding change in its components, i.e. number of nodes and internode length. There was no association between number of nodes and intern- 
ode length indicating that plant height and its components could be improved simultaneously. Improvement in these characters should not be difficult as they had reasonably good variation and moderate to high heritability and genetic advance. However, these characters are of little value for improving tuber yield as correlation coefficients between these characters and tuber yield or its components were, in general, non-significant. In this regard our findings differ from those of Singh and Singh [20] and Maris [15] who reported a significant association between plant height and tuber yield. Our findings, however, are in agreement with those of Patel et al. [16], Sidhu et al. [18] and Desai and Jaimini [6]. Dayal et al. [5] reported a significant association between number of nodes and tuber yield.

Among the other foliage characters, namely number of stems, plant posture, maturity and plant vigour, only plant vigour had a consistently significant association with tuber yield. The moderate and negative associations between these traits indicate that vigorous clones (i.e. those with lower scores in the present study) are expected to have a higher tuber yield. Reasonably good variation and consistently high heritability and genetic advance for plant vigour suggest that selection for plant vigour should be effective.

Maris [15] found a significant relationship between tuber yield and maturity indicating that high yielding genotypes may be late in maturity. However, no such consistent relationship was observed in the present as well as in some other studies $[6,13,24]$. Furthermore, plant vigour and average tuber weight which were related to tuber yield, in general, had no association with maturity. Thus, the clones selected for plant vigour, average tuber weight and tuber yield are not expected to comprise only late types.

Breeder's preference score was based on all the visual characters at harvest, i.e. tuber yield, tuber number, average tuber weight, tuber colour, tuber shape, eye depth, tuber cracking, uniformity in tuber size, etc. In general, non-significant correlation coefficients of breeder's preference score with tuber yield and its components suggest that while recording this trait, no undue preference was given to tuber yield and its components. Breeder's preference score had a high heritability in both seasons and years within a season. It also had a consistently uniform coefficient of variation. Thus, selection for this trait should be effective in identifying clones with superior overall worth.

Some character associations were significant in only the autumn or spring season. These were, however, not of any importance to tuber yield (table III). Some associations were significant in only one year for the autumn and/or spring season indicating that they cannot be relied upon for use in breeding programmes. This, however, stresses the need for conducting such studies over years and seasons and also explains the variation observed among results obtained in earlier studies.

\section{Conclusion}

Simultaneous selection for plant vigour, average tuber weight and tuber yield should be effective in improving overall yield in the potato. Breeder's preference score at harvest should be a good guide to improve the overall worth of a clone for various agronomic characters of economic importance. This strategy could be adopted for potato breeding programmes in both the autumn and spring seasons in the sub-tropical north-western plains of India.

\section{References}

[1] Anderson J.A.D., Howard H.W., Effectiveness of selection in early stages of potato breeding programmes, Potato Res. 24 (1981) 289-299.

[2] Birhman R.K., Kaul M.L.H., Variability components and genetic parameters in andigena potato, Biol. Zent. bl. 108 (1989) 209-219.

[3] Brown J., Caligari P.D.S., Mackay G.R., Swan G.E.L., The efficiency of visual selection in early generations of a potato breeding programme, Ann. Appl. Biol. 110 (1987) 357-363.

[4] Chaudhary S.K., Sharma S.K., Genetic variability for yield and its components in potato breeding material, Ind. J. Agric. Sci. 54 (1984) 941-942. 
[5] Dayal T.R., Upadhya M.D., Malhotra V.P., Mehra K.L., Heritability and correlation in yield and other quantitative characters in potato (Solanum tuberosum L.), Ind. J. Agri. Sci. 42 (1972) 464-466.

[6] Desai N.C., Jaimini S.N., Correlation and path analysis of some economic characters in potato, J. Ind. Potato Assoc. 25 (1998) 25-29.

[7] Garg L.P., Bhutani R.D., Studies of correlation and path analysis in potato, Haryana J. Hort. Sci. 20 (1991) 255-260.

[8] Gaur P.C., Gupta P.K., Kishore H., Genetic components of tuber yield and quality characters in potato, J. Ind. Potato Assoc. 5 (1978) 32-37.

[9] Gaur P.C., Kishore H., Gupta P.K., Studies on character association in potatoes, J. Agric. Sci. Camb. 90 (1978) 215-219.

[10] Gopal J., Minocha J.L., Effectiveness of in vitro selection for agronomic characters in potato, Euphytica 103 (1998) 67-74.

[11] Gopal J., Gaur P.C., Rana M.S., Early generation selection for agronomic characters in a potato breeding programme, Theor. Appl. Genet. 84 (1992) 709-713.

[12] Gopal J., Gaur P.C., Rana M.S., Heritability, and intra- and inter-generation associations between tuber yield and its components in potato (Solanum tuberosum L.), Plant Breed. 112 (1994) 80-83.

[13] Killick R.J., Genetic analysis of several traits in potatoes by means of a diallel cross, Ann. Appl. Biol. 86 (1977) 279-289.

[14] Maris B., Studies on maturity, yield, under water weight and some other characters of potato progenies, Euphytica 18 (1969) 297-319.
[15] Maris B., Correlations within and between characters between and within generations as measure for the early generation selection in potato breeding, Euphytica 37 (1988) 205-226.

[16] Patel O.P., Patel R.M., Mandloi K.K., Sikka L.C., Genetic variability and correlation studies in potato, Haryana J. Hort. Sci. 2 (1973) 72-75.

[17] Sidhu A.S., Pandita M.L., Genetic variability and correlation studies in potato (Solanum tuberosum L.), J. Ind. Potato Assoc. 6 (1979) 103-108.

[18] Sidhu A.S., Pandita M.L., Arora S.K., Path coefficient analysis in potato, J. Ind. Potato Assoc. 7 (1980)159-161.

[19] Singh R.K., Chaudhary B.D., Biometrical Methods in Quantitative Genetic Analysis, Kalyani Pub., Ludhiana, New Delhi, 1977.

[20] Singh R.P., Singh R.P., Correlation of some plant characters with yield in potato, J. Ind. Potato Assoc. 14 (1987) 124-126.

[21] Tai G.C.C., Estimates of general and specific combining abilities in potato, Can. J. Genet. Cytol. 18 (1976) 463-470.

[22] Tarn T.R., Tai G.C.C., Heterosis and variation of yield components in F1 hybrids between group Tuberosum and group Andigena potatoes, Crop Sci. 17 (1977) 517-521.

[23] Thompson P.G., Mendoza H. A., Genetic variance estimates in a heterogenous potato population propagated from true seed (TPS), Am. Potato J. 61(1984) 697-702.

[24] Thompson P.G., Mendoza H.A., Plaisted R.L., Estimation of genetic parameters for characters related to potato propagation by true seed (TPS) in an andigena population, Am. Potato J. 60 (1983) 393-401. 